\title{
Development of Interactive E-Module for Global Warming to Grow of Critical Thinking Skills
}

\author{
Wayan Suwatra ${ }^{1}$, Agus Suyatna ${ }^{2 *}$, Undang Rosidin ${ }^{2}$ \\ ${ }^{1}$ SMAN 9 Bandar Lampung, Indonesia \\ ${ }^{2}$ Physics Education Department, Lampung University, Bandar Lampung, Indonesia \\ *Corresponding author:asuyatna@yahoo.com
}

\begin{abstract}
Critical thinking skills are important for solving global warming problems. This critical thinking skill is grown through learning with an interactive emodule for global warming designed to cultivate critical thinking skills.The purpose of this research is to develop an interactive e-module for critical thinking skills on global warming. This research was designed with Research and Develomment $(R \& D)$. The product has been validated by the design of the learning expert through the assessment and qualitatively analyzed descriptive. The product was tested with a quasi experimentsNon-equivalent control group pretestposttest.Classroom experimental learning using an interactive e-module, but control class learning using conventional books. The test subjects are students from one high school in Bandar Lampung. The result is that the average of $N$-gain of experiment class is higher than control class, that is 0.77 for the experimental class and 0.55 for the control class. The ability of critical thinking skills on global warming for the experimental class increased significantly by $95 \%$. In conclusion e-module interactive global warming can cultivate critical thinking skills.
\end{abstract}

Keywords- interactive e-Module, critical thinking, global warming.

\section{INTRODUCTION}

Global warming is one of the environmental issues of rising earth temperatures due to rising greenhouse gas emissions in the atmosphere caused by human attitudes. Shepardson et al (2011) states that temperature changes impact climate change, rainfall patterns and bad weather. Climate change in Indonesia such as changes in the rainy season, the length of the dry season, floods, whirlwinds, and others.

The impact of global warming can be reduced by understanding the effects of global warming. Students are expected to have a critical attitude on the behavior of greenhouse gas donations. Therefore, the Government of Indonesia is making global warming a part of the curriculum of junior and senior secondary schools (Curriculum Developing Team, 2014). The government's move is positive and relevant to current conditions.
Rosidin and Suyatna (2017) showed that the understanding of Indonesian students about global warming is very low. This not only happens in Indonesia, according to Yazdanparast et al, (2013) students do not have enough information about the phenomenon of globalization. Shepardson et al (2011) says there are still middle school students from the Midwest who are confused about the greenhouse effect and the type of radiation in the greenhouse effect. Efforts to grow critical thinking skills have been done, such as by Susanto, et al (2016) by developing interactive multimedia. Maria et al. (2016) by developing the Learning Cycle 7E student worksheet. Novrizawati, et al. (2017) by developing TRAPI learning model, but has not obtained optimal results. This problem will be tackled by providing an interactive e-module that can cultivate critical thinking skills on global warming, especially in the formation of greenhouse gases in the atmosphere caused by human behavior.Communication information technology (ICT) as a learning resource an innovative learning process where the learning process becomes more varied, not limited by space, time and age. One of the real forms of ICT as a learning resource is the interactive electronic module. According to Susanto et al (2015) the use of interactive multimedia global warming is more effective than conventional learning. Provision of stimulus can train students' critical thinking skills, which can be done in learning (Snyder \& Snyder, 2008). Critical thinking skills can be achieved through investigation-based learning (Ching and Fong, 2013). Students can acquire knowledge, behavior, and skills by learning materials (Dimyati and Mudjiono, 2013).

Learning is the process by which a person undertakes to obtain a whole new change of behavior as a result of his own experience in interaction with his environment (Slameto, 2013). Related to that, one of the ways that can be taken is to optimize the use of techno-logical development in the preparation of teaching materials. Available teaching materials are generally static, so less able to cultivate the power of critical thinking, creative, innovative and care about the environment. If in the study of physical matter displayed natural phenomena in the form of animation and video, then learners as if 
experiencing phenomena observed. The concept of global warming can be easily understood and long-lasting when learning is related to everyday life and packed interesting so as to motivate students to learn. Teaching materials can be packaged in the form of conventional books or electronic modules. Innovations in electronic modules, can be designed interactively and incorporate technologies that develop in time. The contents of the interactive electronic module of the students are more varied by incorporating moving images (video), animation, simulation, and materials in an integrated manner.

In learning physics students not only hear, record and remember from the subject matter presented by the teacher, but more emphas is on the ability of students to be able to solve problems and act (make observations, experiment, discuss a problem, answer questions and apply concepts and laws to solve the problem) tothe learned, then communicate the results. The interactive electronic module for students can be a guideline in the learning process, as well as a means of evaluating the achievement of learning outcomes. Student learning outcomes can be formulated through a well-structured learning process using appropriate models, instructional materials, and assessments. TRAPI learning model can improve critical thinking ability (Novrizawati, et al., 2017) and Authentic assessment of global warming materials in the learning process can improve student's critical thinking ability (Damayanti, et al., 2017). According to Ennis, (1996) that the sub-ability of critical thinking is deciding what action should be trusted or done. These measures accommodate what needs to be done to achieve the learning objectives that have been formulated.The result of observation at high school in Bandar Lampung is from 30 students who were questioned in $80 \%$ of students did not know the cause of global mobilization, $73 \%$ of students can not mention the effect of global warming properly and $50 \%$ of students do not understand the action to be done related to reducing global warming and $75 \%$ of teachers have not used student-centered teaching materials and $75 \%$ of teachers do not have special teaching materials to teach students. One of the causes of the incompleteness of understanding consept in learning caused special teaching materials supporting learning global warming. This study aims to develop interactive electronic module of global warming that can be used to cultivate critical thinking skills of high school students.

The concept of global warming can be easily understood and long lasting when learning related to everyday life and packed interesting, according to Duron et al., (2006) student's critical thinking ability can be optimized through 5 steps that is determining the purpose of learning, experiments before drawing conclusions, providing feedback and assessment of learning, so that critical thinking skills and student learning outcomes can be improved, these 5 steps are written on an interactive emodule. Thedeveloped interactive module incorporates video elements, images, graphics, sound, animation and simulations that support to achieve maximum learning and can grow critical thinking skills.

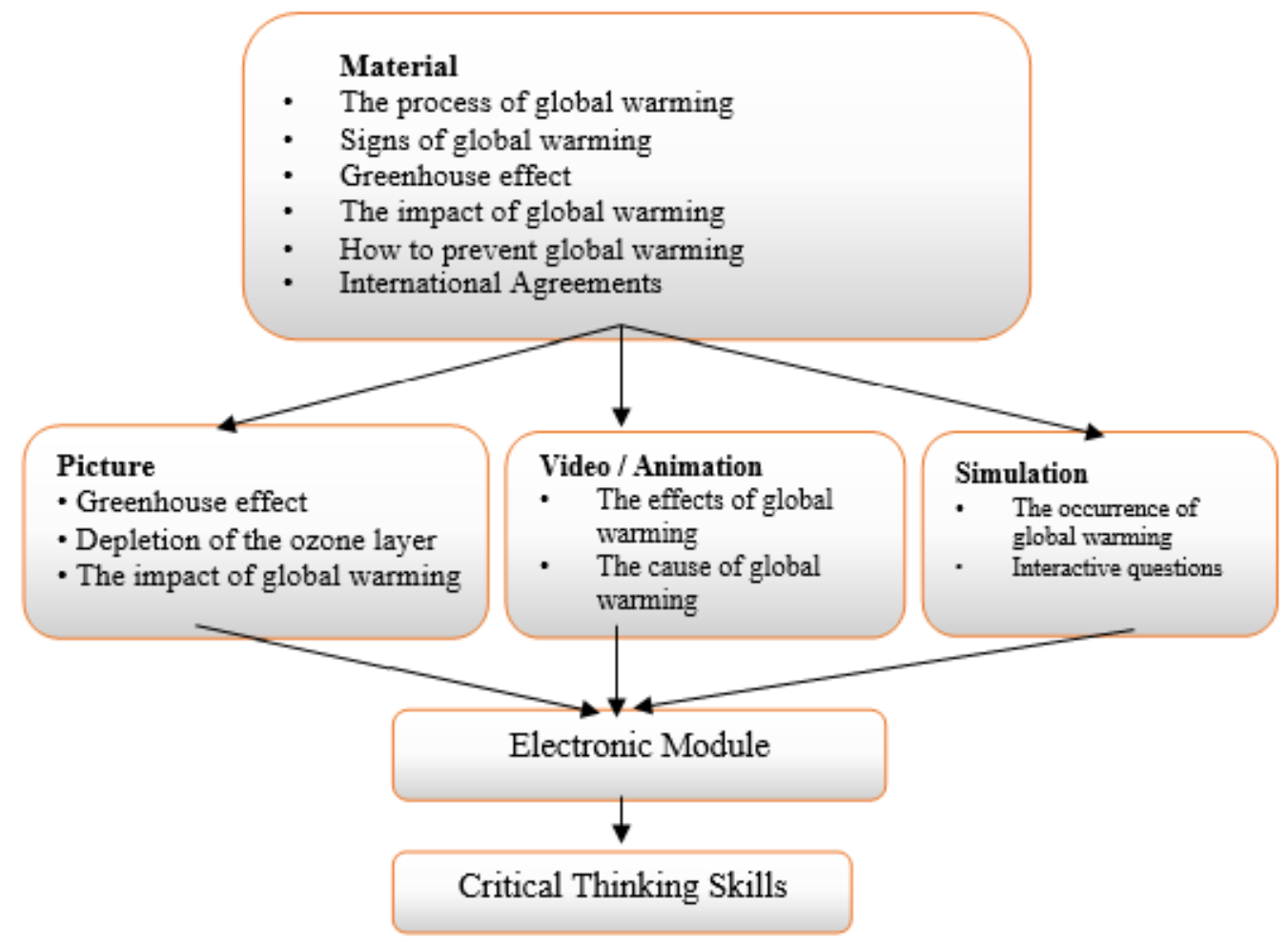

Fig.1: The flow of Electronic Subject Materials 


\section{METHOD}

The development model used is research and develomment (R \& D) according to Borg \& Gall (2003). The implementation of this research is limited to the seventh step, ie 1) preliminary research, 2) planning, 3) initial product development, 4) initial product testing, 5) product revision, 6) revision test, 7) final product. Validation of teaching material product is done by 3 experts and 4 practitioners in physics lesson. Intrumen validation test of e-module experts using questionnaires. Data analysis of validation test result was done using descriptive quantitative analysis. The effectiveness of emodules is determined by comparing student learning outcomes using e-modules with students learning using printed modules and by comparing pre-test with posttest results. The e-module implementation test is carried out at high school in Bandar Lampung. The experimental design of the product used was a quasi experiment with pre-test post-test control group design. The subject of the emodule usage test is the student of class XI IPA1 as the experimental class and XI IPA2 as the control class using the printed module. The test subject is determined by purposive sampling taking into account the equivalence of the experimental class with the control class. The data were analyzed using statistical test ie normality test, homogeneity test, test of $n$-gain average difference of control class with experiment class (independent sample $\mathrm{t}$-test), test the average difference pretest with posttest (paired sample t- test). $\mathrm{N}$-gain is calculated using the Hake (1999) formula as follows.

N-gain $(<\mathrm{g}>)=\frac{(\%<S f>-\%<S i>)}{(100-\%<S i>)}$

Information:

$\mathrm{g} \geq 0.7$ high category

$0.3 \leq \mathrm{g}<0.7$ medium category g $<0.3$ low category

\section{RESULTS AND DISCUSSION}

In the early stages of the study, preliminary research was conducted to find out how the initial concept of global warming materials of students and how the need of teaching materials of students/teachers. The results of a questionnaire distributed by one of the high schools in Bandar Lampung are $80 \%$ of students can not answer the question about the causes of global warming in detail and $75 \%$ of teachers have not used special teaching materials global pemorientan material. According to Situmorang et al, (2005) that instructional innovation is needed especially to produce learning that can give better learning result toward renewal, innovation on teaching materials can be done by adopting technology. By utilizing technological progress, electronic textbook development can be maximized to convey material on learning according to Djamarah, (2000). Interactive electronic modules can make it easier to include sound, video, animation and simulation elements (Dwiyoga, 2013). Development of interactive electronic module after the preliminary research subsequently design and develop interactive emodule consisting of:

\section{a) Introduction}

The introductory section consists of cover, usage instructions and core competency (CC) analysis, bacic competency (BC), indicator. The introductory section of the design is as interesting as possible in terms of colors, images, and animations so as to keep learners interested and motivated to learn.

Table.1: Opening / Introduction Section

\begin{tabular}{|l|l|l|}
\hline Cover & \multicolumn{1}{|c|}{ Instructions } & \multicolumn{1}{c|}{$\begin{array}{c}\text { Analysis of CC, BC, } \\
\text { indicators }\end{array}$} \\
\hline $\begin{array}{l}\text { The front cover of the } \\
\text { interactive e-module }\end{array}$ & $\begin{array}{l}\text { The instructions contain } \\
\text { navigation instructions for } \\
\text { using interactive modules. }\end{array}$ & $\begin{array}{l}\text { Introduction contains of KI, } \\
\text { KD, and indicator. }\end{array}$ \\
\hline
\end{tabular}


b) Content / material section

The content section dis plays the stages of the activities of each material to be conveyed. Learning stages use TRAPI learning model on global warming materials to improve students' critical thinking skills (Novrizawati, et al., 2017).

Table.2: Part Content of interactive e-module

\begin{tabular}{|l|l|l|l|}
\hline $\begin{array}{l}\text { Global Warming } \\
\text { Opening Matter }\end{array}$ & $\begin{array}{l}\text { Signs and Causes of } \\
\text { Global Warming }\end{array}$ & $\begin{array}{l}\text { Global warming } \\
\text { impacts and } \\
\text { mitigation }\end{array}$ & $\begin{array}{l}\text { International } \\
\text { Agreements Global } \\
\text { warming }\end{array}$ \\
\hline $\begin{array}{l}\text { Contains material } \\
\text { delivering signs of } \\
\text { global warming and } \\
\text { there are animated } \\
\text { and video } \\
\text { phenomenon and } \\
\text { contains material } \\
\text { about the causes of } \\
\text { the occurrence of } \\
\text { global warming }\end{array}$ & $\begin{array}{l}\text { Contains introductory } \\
\text { materials on the } \\
\text { global warming } \\
\text { process and } \\
\text { animation as well as } \\
\text { video phenomena of } \\
\text { global warming. }\end{array}$ & $\begin{array}{l}\text { Contains about a volt } \\
\text { meter animation that } \\
\text { can be used for } \\
\text { demonstration of volt } \\
\text { meter and contains } \\
\text { about how to cope } \\
\text { with global warming. }\end{array}$ & $\begin{array}{l}\text { Contains material on } \\
\text { the International } \\
\text { Agreement relating to } \\
\text { global warming }\end{array}$ \\
\hline
\end{tabular}

a) Final part of e-module interactive

The cover section of the student's counseling test contains interactive questions that can test the level of students' understanding of global warming materials.
After the interactive electronic module planning is completed then the product validation test is done by content / material experts, constructors, and linguists.

Table.3: Results of Expert Validation Test

\begin{tabular}{|l|c|c|c|}
\hline No. & type of test & Validator & Category \\
\hline 1 & Validation contents & 3.40 & Very good \\
\hline 2 & construct Validation & 3.29 & Very good \\
\hline 3 & Validation language & 3.40 & Very good \\
\hline
\end{tabular}

The interactive e-module effectiveness test is performed by analyzing the pretest and posttest results of students' critical thinking skills on the causes and impacts of global warming as well as ideas for addressing the effects of global warming. The results of the effectiveness analysis are presented in Table 4.

Table.4: Test the average difference between pretest and posttest critical thinking skills

\begin{tabular}{|c|c|c|c|c|}
\hline \multicolumn{1}{|c|}{ Treatment } & $\begin{array}{c}\text { The average } \\
\text { value of pretest }\end{array}$ & $\begin{array}{c}\text { Value } \\
\text { On average posttest }\end{array}$ & N-gain & p \\
\hline $\begin{array}{l}\text { interactive e-module } \\
\text { (experimental group) }\end{array}$ & 34.40 & 81.06 & 0.57 & 0,00 \\
\hline $\begin{array}{l}\text { Textbooks available } \\
\text { (Control group) }\end{array}$ & 34.80 & 71.20 & 0.72 & 0,00 \\
\hline $\mathrm{p}$ & 0.859 & 0,00 & & - \\
\hline
\end{tabular}


The pretest giving based on table 4 obtained the average pretest result of the class using the electronic material is 34.40 and the average pretest for the class using the available book 34.80 . The results of independent sample t-test showed the students' average early ability in the class using interactive e-learning module and the class using the book no difference ( $p=0.859>0.05$ ). After the learning process where the experimental class using electronic module and control class using printed book done post-test. The average class posttest uses an 81.06 interactive electronic module and a pretest average value for a class that uses printed books 71,20.

The post-test analysis concludes that there is an experimental $\mathrm{N}$-gain class that uses an interactive electronic module with a control class that uses textbooks.
The critical thinking skills of students acquiring learning using interactive electronic modules increased significantly at the $95 \%$ confidence level $(\mathrm{P}=0.000$ $<0.05)$ from 34.40 to 81.06 . The average increase in classes using the interactive e-module obtained $\mathrm{N}$-gain of 0.76 with the high category, while the class using textbook material printed printed obtained $\mathrm{N}$-gain of 0.57 with medium category. It appears that the use of emodules is more effective in improving students' critical thinking skills about global warming. To further examine the effect of e-module utilization, data analysis is based on each indicator of critical thinking skill. The results are shown in Table 5. It appears that all the indicators of critical thinking skills of the experimental class are significantly higher than the control class.

Table.5: Average N-Gain of Critical Thinking Skills Each Indicator

\begin{tabular}{|c|c|c|c|c|c|c|}
\hline \multirow{2}{*}{$\begin{array}{l}\text { No. } \\
\text { Quest } \\
\text { ion }\end{array}$} & \multirow[b]{2}{*}{ Critical Thinking Indicators } & \multicolumn{4}{|c|}{ Class } & \multirow[b]{2}{*}{$\mathbf{P}$} \\
\hline & & Experiment & Criteria & Control & Criteria & \\
\hline 1 & Analyzing arguments. & 0.72 & High & 0.56 & moderate & 0.00 \\
\hline 2 & $\begin{array}{l}\text { Defining the term and consider a } \\
\text { definition. }\end{array}$ & 0.87 & High & 0.60 & moderate & 0.00 \\
\hline 3 & $\begin{array}{l}\text { Consider whether the source is reliable } \\
\text { or not. }\end{array}$ & 0.87 & High & 0.53 & moderate & 0.00 \\
\hline 4 & $\begin{array}{l}\text { Ask and answer questions of clarification } \\
\text { and critical questions. }\end{array}$ & 0.81 & High & 0.61 & moderate & 0.00 \\
\hline 5 & $\begin{array}{l}\text { Induce and consider the results of the } \\
\text { induction. }\end{array}$ & 0.65 & moderate & 0.60 & moderate & 0.00 \\
\hline 6 & Decide a course of action. & 0.81 & High & 0.45 & moderate & 0.00 \\
\hline 7 & $\begin{array}{l}\text { Making and reviewing the results of } \\
\text { consideration of values. }\end{array}$ & 0.62 & moderate & 0.55 & moderate & 0.00 \\
\hline 8 & $\begin{array}{l}\text { Deducing and consider the results of } \\
\text { deduction. }\end{array}$ & 0.87 & High & 0.56 & moderate & 0.00 \\
\hline \multirow[t]{2}{*}{9} & Analyzing arguments. & 0.72 & High & 0.56 & moderate & 0.00 \\
\hline & Average & 0.76 & High & 0.56 & moderate & 0.00 \\
\hline
\end{tabular}

According to Anori et al (2013) that the use of e-book in direct learning model has a positive and significant impact on student learning outcomes. It also uses technology to create and combine text, graphics, audio, video by using tools that enable users to interact, create, and communicate (Rosida, 2015). Multimedia-assisted learning can be designed to turn learning into an active process. Learning media can represent what teachers are less able to say through a particular speech or sentence, with technological innovation can also increase students' interest in learning the material to be taught (Djamarah, 2000). Factors that influence the learning outcomes in this study are media and teaching materials as a source of learning. Learning innovation is needed especially to produce new learning that can give better learning result toward renewal, as well as one of the must possess of teaching material that is interesting appearance in teaching materials so that can motivate student to learn (Holliday, 2002). Innovation in teaching materials can be done by adopting new technologies to improve content, illustrations, presentations and graphics (Situmorang and Saragih, 2012).

In table 5 the critical thinking indicator that obtains high category results is the definition of terms and define a definition, consider whether the source is reliable or not, ask questions and answer clarification questions and critical questions, decide an action, and deduce and consider the outcome deduction. Of the nine indicators of critical thinking, seven indicators experienced a high category increase, while the two indicators were induced and considered induced results and assessed the values of the considerations increased in the medium category. This 
can be caused by the design of interactive electronic modules still can not lead students in inducing and considering induced results, as well as creating and reviewing the values of the results of consideration. Snyder \& Snyder (2008) reveals that critical thinking embodies training, practice, and patience. This interactive electronic module that is produced enables students to systematically study the problem so that critical thinking ability can be grown (Kartimi and Permanasari, 2012). It also supports the existence of integrated multimedia in module enabling the module to be an effective learning resource, as the research results Susanto et al (2017) by using interactive multimedia of global warming can cultivated critical thinking skills of students.

\section{CONCLUSION}

Global warming interactive e-module that integrates global warming images/phenomena, videos on the causes of global warming, global warming simulations, animated impacts of global warming for life on earth, and interactive practice exercises can foster critical thinking skills of high school students. The interactive e-module of global warming development results as sessed by students to have appeal, usefulness, and easy to operate.

\section{REFERENCES}

[1] Anori, S., A. Putra, \&Asrizal. (2013). The Influence of Electronic Textbook Usage in the Direct Learning Model of Student Results of Class X SMAN 1 LubukAlung. Pillar of PhysicsEducation 1 (1): 104111.

[2] Borg, W. R, \& Gall, M. D., Gall, J. P. (2003). Educational Research: An Introduction (Seventh Edition ed.). United States: Pearson Education, Inc.

[3] Ching, H. S., \& Fong, S. F., (2013). Effects of multimedia-based graphic novels presentation on critical thinking among students of different learning approaches. TOJET: The Turkish Online Journal of Education, 12 (4).

[4] Damayanti, R. S., Suyatna, A., Warsono, W., \&Rosidin, U. (2017), Development of Authentic Assessment instruments for Critical Thinking skills in Global Warming with a Scientific Approach. International Journal of Science and Applied Science: Conference Series, 2 (1), 289-299.

[5] Djamarah, S.B., (2000), Teachers and Students in Educational Interaction, Publisher RinekaCipta, Jakarta.

[6] Dimyati and Mudjiono (2013). Learning and Learning. PT RinekaCipta, Jakarta

[7] Duron, R., Limbach, B., \& Waugh, W. (2006). Critical thinking framework for any discipline. International Journal of Teaching and Learning in Higher Education, 17 (2), 160-166.
[8] Ennis, H Robert. (1996). Critical Thinking. University of Illinois: Prentice Hall, Upper Saddle River, New Jersey 07458.

[9] Hake, R.R. (1999). Interactive-engagement vs traditional methods: A six thousand student survey of mechanics test data for introductory physics courses. American Journal of Physics, 66, 64-74, from http: //aapt.scitation. org / doi / abs / 10.1119 / 1.18809

[10] Holliday, W. G., (2002), Selecting A science Textbook, Science Scope, 25 (4): 16

[11] Kartimi, L., \&Permanasari, A. (2012). Development of Critical Thinking Measures on Concepts of Hydrocarbon Compounds for High School Students in Kuningan District. Journal of MIPA Education, 13 (1), 18-25.

[12] Maria, L., Suyatna, A. and Warsito. (2016). Development of Learning Students Worksheet (LKPD) Learning Cycle 7E Global Warming Materials to Cultivate Student Critical Thinking Skills. Journal of Physics Learning. 4 (5)

[13] Novrizawati, F., Suyatna, A., \&Fadiawati, N. (2017). Effectiveness of the Application of Tradis' Learning Model to Cultivate Critical Thinking Skills. Journal of Physics Learning, 5 (1), 97-106

[14] Rosida, Imran. (2015). Development of Scientific Approach-Based Module as a Supporting Material for Implementation of Curriculum 2013 On Special Journal Material. Journal of Accounting Education, 3 (http://ejournal.unesa.ac.id/index.php/jmpt/article/vi ew/12561, accessed April 08, 2017).

[15] Rosidin, U \&Suyatna, A. (2017). Teachers and Students Knowledge about Global Warming: a Study in the Smoke Disaster Area of Indonesia. International Journal Of Environmental Science \& Education, 12 (4), 777-785

[16] Situmorang, M. \&Saragih, N., (2012), Development of High School Chemical Learning Module Through Innovation and Integration Character Education To Prepare Characteristic Resource Facing Global Competition, Journal Litjak (In Press).

[17] Slameto (2013). Learning and Influencing Factors. RinekaCipta, Jakarta

[18] Shepardson, D. P., Niyogi, D., Choi, S., \&Charusombat, U, (2011). Students' Conceptions About The Greenhouse Effect, Global Warming, And Climate Change. Climatic Change, 104 (3), 481-507

[19] Susanto, B., Suyatna, A. \&Warsito (2015). Design Learning Media of Global Warming Based On Interactive Multimedia With Scientific Approach To Improve Critical Thinking Skills. In Proceeding of 
The Third South East Asia Design / Development Research International Conference.

[20] Susanto, B., Suyatna, A. \&Warsito. (2016). Multimedia Interaktfi Global Warming with Scientific Approach to Improve Student's Critical Skills. Journal of Physics Learning. 4 (5), 113-122

[21] Snyder, L. G., \& Snyder, M. J. (2008). Teaching critical thinking and problem solving skills The Journal of Research in Business Education, 50 (2)

[22] Yazdanparast, T., Salehpour, S., Masjedi, M. R., Seyedmehdi, S. M., Boyes, E., Stanisstreet, M. \&Attarchi, M, (2013). Global warming: knowledge and views of Iranian students. ActaMedicaIranica, 51 (3), 178-184. 